\title{
PENGARUH PENERAPAN MODEL CORE DENGAN PENDEKATAN KONTEKSTUAL TERHADAP KEMAMPUAN PEMECAHAN MASALAH MATEMATIKA SISWA SMA
}

\author{
${ }^{1}$ Mardiati; ${ }^{2}$ Ice Wirevenska; ${ }^{3}$ Sri Zulhayana \\ ${ }^{1}$ STKIP Budidaya Binjai Prodi Pendidikan Matematika \\ ${ }^{1}$ Ice.wr08@gmail.com \\ ${ }^{2}$ STKIP Budidaya Binjai Prodi Pendidikan Matematika \\ ${ }^{2}$ Mardiati2208@gmail.com \\ ${ }^{3}$ STKIP Budidaya Binjai Prodi Pendidikan Matematika \\ 3sri_zet@yahoo.com
}

\begin{abstract}
ABSTRAK
Tujuan Penelitian ini adalah untuk mengetahui pengaruh Model CORE (Connecting, Organizing, Reflecting, Extending) dalam pembelajaran matematika dengan pendekatan kontekstual terhadap kemampuan pemecahan masalah matematika siswa SMA. Penelitian ini dilaksanakan di SMA Negeri 1 Selesai. Jenis penelitian yang digunakan adalah eksperimen semu. Populasi dalam penelitian ini adalah siswa kelas X SMA Negeri 1 Selesai Tahun Pelajaran 2019-2020. Sampel dalam penelitian ini berjumlah 60 siswa dengan pengambilan sampel secara acak. Data kemampuan dasar matematika siswa dan kemampuan pemecahan masalah matematika siswa diperoleh dari hasil instrumen yang diberikan berupa tes yang terdiri dari 5 soal uraian. Data dianalisis menggunakan uji analisis kovarian. Hasil penelitian menunjukkan (1) terdapat perbedaan kemampuan pemecahan masalah matematika antara siswa yang menggunakan pembelajaran model CORE dengan pendekatan kontekstual dan konvensional; (2) setelah kemampuan dasar matematika dikendalikan terdapat perbedaan kemampuan pemecahan masalah matematika antara siswa yang menggunakan pembelajaran model CORE dengan pendekatan kontekstual dan konvensional; (3) terdapat kontribusi kemampuan dasar matematika siswa terhadap kemampuan pemecahan masalah matematika siswa.
\end{abstract}

Kata kunci : Model CORE, Pendekatan Kontekstual, Kemampuan Pemecahan Masalah Matematika.

\section{PENDAHULUAN}

Permendiknas No. 22 tahun 2006 menyatakan bahwa tujuan pembelajaran matematika adalah: (1)memahami konsep matematika, menjelaskan keterkaitan antar konsep dan mengaplikasikan konsep atau algoritma secara luwes, akurat, efesien dan tepat dalam masalah, (2)menggunakan penalaran pola dan sifat, melakukan manipulasi matematika dalam membuat generalisasi, menyusun bukti atau menjelaskan gagasan dan pernyataan matematika, (3)memecahkan masalah yang mengikuti kemampuan memahami masalah, merancang model matematika, menyelesaikan model dan menafsirkan solusi yang diperoleh, (4) mengomunikasikan gagasan dengan simbol, tabel, diagram atau media lain untuk memperjelas keadaan atau masalah, dan (5)memiliki sikap menghargai kegunaan matematika dalam kehidupan yaitu memiliki rasa ingin tahu, perhatian dan minat dalam mempelajari matematika serta sikap ulet dan percaya diri dalam pemecahan masalah.

Dari tujuan pembelajaran matematika tersebut, terlihat bahwa salah satu tujuan pembelajaran matematika adalah agar siswa mempunyai kemampuan atau keterampilan dalam memecahkan masalah matematika. Kemampuan pemecahan masalah merupakan salah satu kemampuan yang harus dimiliki siswa. 
Kemampuan pemecahan masalah memegang peranan penting selain sebagai tuntutan pembelajaran matematika, kemampuan tersebut juga bermanfaat bagi siswa dalam kehidupan sehari-hari. Surya (2015:6) mengatakan bahwa: "Pemecahan masalah merupakan salah satu tugas hidup yang harus dihadapi dalam kehidupan seharihari dengan rentangan kesulitan dari yang paling sederhana hingga yang paling kompleks". Adapun menurut Solso, (2007:434) mengatakan bahwa: "Pemecahan masalah adalah suatu pemikiran yang terarah secara langsung untuk menemukan solusi atau jalan keluar untuk suatu masalah yang spesifik". Hal senada disampaikan oleh Hamalik seperti dikutip oleh Zulkarnain (2015:43) mendefinisikan bahwa Pemecahan masalah sebagai suatu aktivitas yang berhubungan dengan pemilihan jalan keluar atau cara yang cocok bagi tindakan dan pengubah kondisi sekarang menuju kepada situasi yang diharapkan.

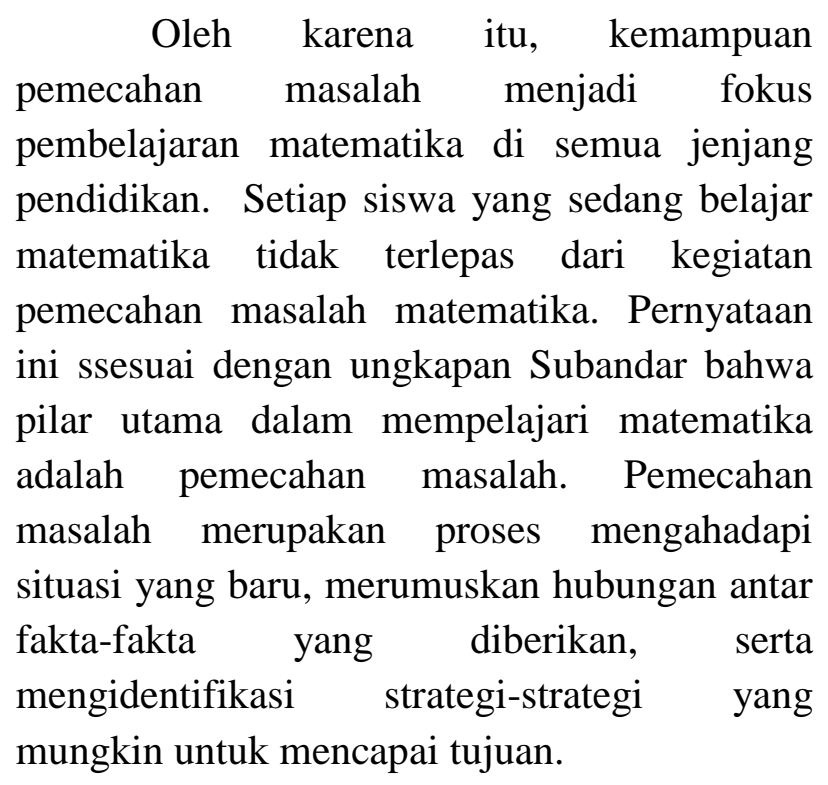

Untuk menyelesaikan suatu masalah diperlukan beberapa langkah yang sistematik. Menurut Polya (1975:6) menyatakan bahwa: "Terdapat empat langkah dalam pemecahan masalah yaitu: (a)memahami masalah, (b)menyusun rencana, (c)melaksanakan rencana, (d)mengecek kembali”.

Kemampuan pemecahan masalah perlu dikuasai siswa guna mendorong mereka menjadi seorang pemecah masalah yang baik, yang mampu menghadapi masalah dalam kehidupan sehari-hari maupun dalam dunia kerja. Akan tetapi pada kenyataannya kemampuan pemecahan masalah matematika siswa masih rendah.

Sebelum melakukan penelitian ini terlebih dahulu dilakukan studi pendahuluan melalui wawancara dan observasi yang dilakukan terhadap siswa di SMA Negeri 1 Selesai. Berdasarkan hasil wawancara dengan guru matematika dan juga hasil observasi dengan beberapa siswa diperoleh bahwa: (1)hasil belajar matematika masih rendah; (2)siswa kurang mampu dalam memahami soal cerita yang diberikan; (3)siswa kurang mampu menyelesaikan soal-soal yang tidak rutin; (4)siswa hanya mampu menyelesaikan soalsoal yang mirip dengan contoh soal yang diberikan oleh guru; (5)siswa lupa dan tidak mengetahui rumus mana yang akan digunakan dalam menyelesaikan masalah matematika

Hasil studi pendahuluan diatas menunjukkan bahwa kemampuan siswa yang rendah dalam memahami dan menyelesaikan masalah matematika yang diberikan salah satunya dalam bentuk soal cerita. Siswa mengalami kesulitan dalam mengatur straategi dan langkah-langkah dalam menyelesaikan masalah matematika terutama dalam bentuk soal cerita.

Hasil wawancara dengan siswa beberapa hal yang menyebabkan siswa masih rendah dan kurang mampu memahami dan menyelesaikan masalah matematika 
dikarenakan siswa kurang berminat dalam pelajaran matematika karena matematika dianggap pelajaran yang sulit dan terlalu banyak rumus-rumus yang harus diingat. Siswa juga merasa pembelajaran matematika itu sering membosankan karena siswa kurang dilibatkan dalam proses pembelajaran. Guru dalam menyampaikan materi dan memberikan contoh soal berbeda dengan soal latihan. Soal latihan lebih rumit daripada contoh sol.

Siswa belum terlibat penuh dalam proses pembelajaran matematika. siswa belum sepenuhnya dibiasakan melakukan kegiatan belajar yang berkaitan dengan memahami masalah, merencanakan strategi penyelesaian masalah, dan belum mengarahkan siswa untuk mengorganisir pengetahuan awalnya.

$\begin{array}{rrr}\text { Berdasarkan permasalahan diatas, } & \text { tindakan untuk }\end{array}$ menyelesaikan masalah pembelajaran matematika yang terdapat di SMA Negeri 1 Selesai. Salah satu solusinya adalah dengan menerapkan model pembelajaran yang inovatif yang melibatkan siswa dalam proses pembelajaran untuk membangun pengetahuannya. Hal ini dikarenakan model pembelajaran merupakan salah satu cara yang digunakan oleh guru untuk beriteraksi dengan siswa guna membangun pengetahuannya dalam proses belajar mengajar.

Sebuah pembelajaran yang dapat menjembati siswa dalam mengembangkan kemampuannya dalam menyelesaikan permasalahan dalam matematika adalah sangat diperlukan. Siswa dapat mengaktifkan pengetahuan awalnya untuk dapat menyelesaikan masalah matematika. Dalam proses pembelajaran siswa diberi suatu permasalahan yang berhubungan dengan konsep yang diajarkan dan siswa dibiarkan mencoba untuk menyelesaikannya dengan arahan guru.

Untuk mencapai kemampuan pemecahan masalah siswa dalam matematika bukanlah hal yang mudah karena dalam memcahkan masalah matematika dilakukan secara individual. Setiap siswa mempunyai kemampuan yang berbeda dalam melakukan pemecahan masalah matematika. Untuk mengatasi masalah tersebut, guru dituntut profesional dalam merencanakan dan melaksanakan pembelajaran. Oleh karena itu, guru harus mampu mendesain pembelajaran matematika dengan metode, teori atau pendekatan yang mampu menjadikan siswa sebagai subjek belajar bukan lagi sebagai objek belajar.

Dalam dunia pendidikan, pemilihan pendekatan dan model pembelajaran yang tepat adalah suatu hal yang harus diperhatikan. Pemilihan pendekatan yang tepat dapat memudahkan siswa untuk memahami materi pelajaran. Salah satu Model pembelajaran tersebut diantaranya adalah model pembelajaran CORE.

Model pembelajaran CORE merupakan salah satu model pembelajaran kooperatif yang terdiri dari empat tahap, yaitu: (1)Tahap Connecting, siswa menghubungkan informasi yang lama dan baru serta dapat menghubungkan antar konsep sehingga siswa memahami masalah dengan membangun keterkaitan antara konsep; (2) Tahap Organizing, tahap ini membantu siswa dalam mengorganisasikan pengetahuannya dalam memahami materi; (3) Reflecting, siswa dibantu dan dilatih untuk dapat menjelaskan informasi yang baru didapatnya dengan memikirkan kembali, mendalami dan menggali; (4) Extending (memperluas), siswa 
mengembangkan, memperluas, menggunakan dan menemukan ide baru dalam memahami permasalahan/materi.

CORE merupakan model pembelajaran dengan metode diskusi yang berdasarkan pada teori kostruktivisme yang bertujuan mengaktifkan dan mengembangkan nalar siswa. Karena dalam menjalankan proses diskusi siswa memerlukan kemampuan untuk menyadari, memilih, dan menggunakan pengetahuan yang dimiliki dan dibutuhkan unutk memecahkan suatu masalah. Dengan demikian pengontruksian pengetahuan juga dilakukan oleh siswa secara mandiri.

Salah satu yang dapat dilakukan guru untuk meningkatkan kemampuan pemecahan masalah matematika siswa dengan memberikan soal-soal penerapan sesuai dengan kehidupan sehari-hari yang kemudian diubah dalam bentuk matematika sehingga dengan diperkenalkannya siswa terhadap masalah yang berhubungan dengan kehidupan sehari-hari maka siswa akan mampu untuk meningkatkan kemampuan pemecahan masalah matematika.

Salah satu konsep belajar yang membantu guru mengaitkan antara materi yang diajarkan dengan situasi dunia nyata dan mendorong siswa membuat hubungan antara pengetahuan yang dimilikinya dengan penerapan dalam kehidupan adalah pendekatan kontekstual (Aqib, 2013:1). Dengan mengaitkan pelajaran akademis dan kehidupan nyata, pembelajaran yang dilakukan akan lebih bermakna sebab siswa akan memahami keterkaitan materi akademis dengan aplikasinya di kehidupan nyata.

Berdasarkan uraian diatas maka rumusan masalah dalam penelitian ini adalah:
(1) Apakah terdapat perbedaan kemampuan pemecahan masalah matematika antara siswa yang menggunakan pembelajaran model CORE dengan pendekatan kontekstual dan konvensional;

(2) Apakah terdapat perbedaan kemampuan pemecahan masalah matematika antara siswa yang menggunakan pembelajaran model CORE dengan pendekatan kontekstual dan konvensional setelah kemampuan dasar matematika siswa dikendalikan?

(3) Apakah terdapat kontribusi kemampuan dasar matematika siswa terhadap kemampuan pemecahan masalah matematika siswa.

\section{METODE PENELITIAN}

Penelitian ini telah dilaksanakan di SMA Negeri 1 Selesai. Populasi dalam penelitian ini adalah seluruh siswa kelas $\mathrm{X}$ MIA SMA Negeri 1 Selesai Tahun Pelajaran 2019/2020 sebanyak 6 kelas, dengan jumlah seluruh populasinya adalah 127 siswa. Sampel dalam penelitian ini adalah kelas XMIA 2 sebagai kelas eksperimen yang menerapkan pembelajaran CORE dengan pendekatan kontekstual dan XMIA 1 sebagai kelas kontrol yang tidak menerapkan model pembelajaran CORE. Jenis penelitian ini merupakan penelitian eksperimen semu. Data penelitian dianalisis menggunakan analisis kovarian satu jalur (One Way Anova). Instrumen yang digunakan untuk mengumpulkan data adalah tes kemampuan dasar matematika sebagai kovariat dan tes kemampuan pemecahan masalah matematika sebagai variable terikatnya.

Hasil dari data penelitian berupa hasil tes kemampuan dasar matematika dan kemampuan pemecahan masalah matematika 
siswa adalah data yang berasal dari data berdistribusi normal dan homogen, selanjutnya dilakukan pengujian hipotesis.

\section{HASIL PENELITIAN DAN PEMBAHASAN}

Berdasarkan tabel (Test Of Between Subjects Effects), untuk menentukan apakah asumsi homogenitas dari regresi terpenuhi atau tidak, maka dapat dilakukan dengan membandingkan nilai sig. pada Metode*KDM terhadap tingkat signifikansi (0,05). Hasilnya nilai sig.(0.081) lebih besar dibandingkan dengan tingkat signifikansi $(0,05)$, maka disimpulkan bahwa asumsi homogenitas dari regresi terpenuhi. Terpenuhinya asumsi homogenitas berarti tidak terjadi interaksi yang begitu signifikan secara statistika antara metode pembelajaran dan kemampuan dasar matematika siswa dalam pengaruhnya terhadap nilai kemampuan pemecahan masalah matematika.

Hasil penelitian menunjukkan bahwa: pertama diperoleh bahwa nilai $\mathrm{F}=$ 9,823 dengan nilai signifikansi, $p=0,003<$ 0,05 . Ini berarti dengan mengontrol kemampuan dasar matematika siswa dapat disimpulkan bahwa terdapat perbedaan nilai kemampuan pemecahan masalah matematika siswa yang menggunakan model pembelajaran CORE pendekatan kontekstual dan pembelajaran konvensional (tujuan penelitian pertama).

Berdasarkan tabel (Test Of Between Subjects Effects) diatas, nilai sig. atau probabilitas untuk variabel metode adalah 0,003. Karena nilai probabilitas untuk variabel metode $(0,003)$ lebih kecil dibandingkan tingkat signifikansi $(0,05)$, maka disimpulkan bahwa terdapat perbedaan yang cukup signifikan secara statistika mengenai rata-rata nilai kemampuan pemecahan masalah matematika antara model pembelajaran CORE dan konvensional dengan mengontrol kemampuan dasar matematika siswa (tujuan penelitian kedua). Metode pembelajaran memiliki pengaruh terhadap kemampuan pemecahan masalah matematika sebesar $14,7 \%$

Selanjutnya untuk nilai sig. atau probabilitas untuk variabel kemampuan dasar matematika, yakni 0,000 . Karena nilai probablilitas untuk variable KDM lebih kecil dibandingkan dengan tingkat signifikansi, maka disimpulkan bahwa terdapat pengaruh atau hubungan yang cukup signifikan secara statistika antara kemampuan dasar matematika terhadap kemampuan pemecahan masalah matematika dengan mengontrol metode pembelajaran (tujuan penelitian ketiga) dengan nilai korelasi sebesar 0,668. Sedangkan kontribusi atau pengaruh kemampuan dasar matematika siswa sebesar $44,7 \%$ terhadap kemampuan pemecahan masalah matematika siswa.

Uji asumsi linieritas digunakan tabel korelasi antara kemampuan dasar dan kemampuan pemecahan masalah matematika siswa, dan diperoleh nilai sig, $(0,000)$ lebih kecil dibandingkan dengan tingkat signifikansi $(0,05)$ maka asumsi linieritas terpenuhi. Artinya penggunaan kovariat kemampuan dasar matematika itu benar-benar cocok.

Hasil dari penelitian ini menunjukkan bahwa model pembelajaran memberikan pengaruh terhadap kemampuan pemecahan masalah matematika, yaitu $14,7 \%$. Walaupun hanya sedikit pengaruhnya hasil penelitian ini menunjukkan bahwa hasil rata-rata kemampuan pemecahan masalah matematika yang diajar menggunakan pembelajaran CORE dengan pendekatan kontekstual lebih tinggi dibandingkan dengan hasil rata-rata 
kemampuan pemecahan masalah matematika siswa yang diajar menggunakan pembelajaran konvensional.

Hasil penelitian ini sejalan dengan penelitian yang dilakukan oleh Desmiyani dan Mardiati dalam jurnal berjudul Pengaruh Pendekatan matematika Realistik (PMR) Terhadap Kemampuan Pemecahan Matematika Siswa Kelas X SMA Negeri 2 Binjai Tahun Pelajaran 2018-2019, menyimpulkan bahwa rata-rata kemampuan pemecahan masalah matematis siswa yang diajar menggunakan pembelajaran matematika realistik (PMR) lebih tinggi dari pada siswa yang diajar dengan pembelajaran konvensional. Pendekatan matematika realistic yang diterapkan dalam penelitian ini memberikan pengaruh yang signifikan terhadap kemampuan pemecahan masalah matematika siswa, sejalan dengan penelitian ini yang juga menerapkan pendekatan kontekstual.

Penerapan model pembelajaran CORE dalam proses pembelajaran matematika masih belum optimal karena model pembelajaran ini serasa baru bagi siswa sehingga beberapa siswa mengalami kesulitan dalam mengikuti tahapan CORE. Pada tahapan connecting siswa mengalami kesulitan walaupun guru sudah melatih siswa untuk mengingat kembali materi sebelumnya. Secara keseluruhan siswa aktif dalam pembelajaran CORE dan memberikan pengalaman belajar kepada siswa karena siswa banyak berperan aktif dalam pembelajaran sehingga pembeljaran tampak bermakna.

Hal tersebut diatas, juga sejalan dengan penenlitian Dewi Satriani, Gusti Ayu Nyoman, Nyoman Dantes, dan I Nyoman Jampel, 2015, yang berjudul: pengaruh penerapan model core terhadap kemampuan pemecahan masalah matematika dengan kavariabel penalaran sistematis pada siswa kelas III Gugus Raden Ajeng Kartini Kecamatan Denpasar Barat. Penenlitian ini menyimpulkan bahwa terdapat perbedaan kemmapuan pemecahan masalah matematika antara siswa yangmengikuti pembeljaran dengan model CORE dengan siswa yang yang mengikuti pembeljaran konvensional.

Berbagai upaya telah dilakukan untuk mendapatkan hasil yang optimal. Oleh karena itu, masih ada beberapa faktor yang sulit dikendalikan sehingga penelitian ini memiliki keterbatasan antara lain:

a. Kondisi siswa yang merasa gugup pada awal proses pembelajaran dengan menggunakan model CORE (Connecting, Organizing, Reflecting, Extending) dengan pendekatan kontekstual karena siswa belium terbiasa.

b. Pada saat berdiskusi masih ada beberapa siswa yang kurang berkontribusi dalam menyelesaikan LAS dan juga dalam memberikan pendapat

c. Masih terdapat siswa yang kurang berinteraksi sebab beberapa siswa terlihat kurang peduli dengan kegiatan yang ada.

d. Alokasi waktu yang kurang sehingga diperlukan persiapan dan pengalokasian waktu yang baik.

\section{IV.PENUTUP}

\section{A. Kesimpulan}

(1) Terdapat perbedaan kemampuan pemecahan masalah matematika antara siswa yang menggunakan pembelajaran model CORE dengan pendekatan kontekstual dan konvensional;

(2) Terdapat perbedaan kemampuan pemecahan masalah matematika antara siswa yang menggunakan pembelajaran model CORE dengan pendekatan 
kontekstual dan konvensional setelah kemampuan dasar matematika siswa dikendalikan?

(3) Terdapat kontribusi kemampuan dasar matematika siswa terhadap kemampuan pemecahan masalah matematika siswa.

\section{B. Saran}

Berdasarkan kesimpulan diatas maka penulis memberikan saran-saran berikut :

1. Bagi siswa, pembelajaran dengan menggunakan model CORE (Connecting, Organizing, Reflecting, Extending) dengan pendekatan kontekstual menjadi salah satu alternative dalam meningkatkan kemampuan pemecahan masalah metematika siswa, karena direspon baik Oleh siswa sehingga pembelajaran ini dapat mengubah cara pandang siswa bahwa belajar matematika bukan hanya sekedar menghapal rumus tetapi juga harus paham dengan konsepnya.

2. Bagi guru, sebagai bahan masukan unutk menggunakan model CORE (Connecting, Organizing, Reflecting, Extending) dengan pendekatan kontekstual dalam meningkatkan kemampuan pemecahan masalah matematika siswa. Model CORE (Connecting, Organizing, Reflecting, Extending) dengan pendekatan kontekstual cenderung lebih membuat siswa lebih aktif siswa karena dalam Model CORE (Connecting, Organizing, Reflecting, Extending) siswa belajar mengkoneksikan informasi lama dan informasi baru, mengorganisasikan ide untuk memahami materi, memikirkan kembali, mendalami dan menggali informasi atau materi ajar, serta mengembangkan, memperluan dan menemukan solusi. Pendekatan kontekstual cenderung lebih menarik perhatian siswa karena siswa belajar dengan menggunakan konsep dunia nyata atau situasi realistik yang dekat dengan siswa.

3. Bagi peneliti selanjutnya, sebagai tambahan wawasan tentang penggunaan model CORE (Connecting, Organizing, Reflecting, Extending) dengan pendekatan kontekstual dalam menjalankan tugas pengajaran sebagai calon tenaga pengajar di masa mendatang.

4. Bagi pembaca, sebagai bahan informasi yang ingin melakukan penelitian sejenis.

5. Bagi lembaga pendidikan, sebagai informasi atau sumbangan pemikiran untuk meningkatkan kualitas pembelajaran yang berkaitan dengan model dan pendekatan pembelajaran.

\section{DAFTAR PUSTAKA}

Dewi Satriani, Gusti Ayu Nyoman, Nyoman Dantes, dan I Nyoman Jampel, 2015, Pengaruh Penerapan Model Core Terhadap Kemampuan Pemecahan Masalah Matematika dengan Kavariabel Penalaran Sistematis pada siswa kelas III Gugus raden Ajeng KartiniKecamatan Denpasar Barat, eJournal Program Pascasarjana Universitas pendidikan Ganesha, volume 5(1)

Eka Lestari, Karunia dan Mokhamad Ridwan Yudhanegara. 2015. Penelitian Pendidikan Matematika. Bandung: Refika Aditama

Mardiati. 2020. Eksperimentasi Model Pembelajaran kooperatif Tipe Numbered Head Together (NHT) terhadap kemampuan Pemahaman Konsep matematis Siswa.Serunai: Jurnal Ilmiah dan Ilmu Pendidikan, 5(2). 171-176

Polya George, 1975, How To Solve It.A.New Aspect Of Mathematical Method, News Jersey Princeton University Press. 
Primayeni, Desmi dan Mardiati, 2019. Pengaruh Pendekatan matematika Realistik (PMR) Terhadap Kemampuan Pemecahan Matematika Siswa Kelas X SMA Negeri 2 Binjai Tahun Pelajaran 2018-2019. Jurnal Ilmiah dan Ilmu Pendidikan. 5(1). 90-94

Shadiq Fajar, 2009, Model-Model Pembelajaran matematika, Yogyakarta: Pusat Pengembangan Dan Pemberdayaan Pendidikan Dan Tenaga Kependidikan (PPPPTK) Matematika.

Solso Robert L., Dkk, 2007, Psikologi Pendidikan, Jakarta: Erlangga.

Surya Mohamad, 2015, Strategi Kognitif Dalam Proses Pembelajaran, Bandung: Alfabeta.

Ulfa, Desnani, Depriwana Rahmi, dan Rena Revita, 2019, Pengaruh Penerapan Model Pembelajaran CORE Terhadap Kemampuan Pemecahan Masalah Matematis Berdasarkan SelfConfidence Siswa SMP/MTS, Journal CendikiaJurnal Pendidikan Matematika, 03(02), 400-409

Zulkarnain Ihwan, 2015, Kemampuan Pemecahan Masalah dan Kemampuan Komunikasi Matematika Siswa,Jurnal Formatif No. 5, Vol. 1. 